\title{
Behavior of Physicochemical Parameters and Potentially Toxic Metals in Surface Water Evaluated by Means of Multimetric Indices: a Case Study in a Protected Natural Area of Peru
}

\author{
María Custodio $^{1 *}$, Carlos Chirinos ${ }^{2}$, Richard Peñaloza ${ }^{1}$ \\ ${ }^{1}$ Universidad Nacional del Centro del Perú, Huancayo, Perú \\ ${ }^{2}$ Mantaro Water Management Authority/National Water Authority
}

Received: 3 March 2019

Accepted: 21 July 2019

\begin{abstract}
The behavior of physical-chemical parameters and potentially toxic metals in the surface water of Lake Chinchaycocha was evaluated using multimetric indices between March and December 2018. Water samples were collected from 10 sampling sites during the rainy and low-water periods, and water quality was determined using the WQI CCME and the Shannon-Wiener index, followed by multivariate analysis. The WQI CCME rated good quality water, except for the LCh1 site. The Shannon-Wiener index rated moderate and extremely contaminated water. The cluster analysis grouped the sampling sites into two clusters with similar characteristics. The ACP presented a total percentage variation of $76.07 \%$. Therefore, this study provides an updated state of the water quality of Lake Chinchaycocha using different indices and multivariate techniques.
\end{abstract}

Keywords: water quality, benthic macroinvertebrates, diversity, multimetric indices, multivariate techniques

\section{Introduction}

Livelihoods in developing countries depend largely on intact and functioning wetlands. Water permanence and quality have been identified as factors affecting the structure and composition of biological communities, such as macroinvertebrates and benthic algae $[1,2]$.

*e-mail: mcustodio@uncp.edu.pe
The natural variability of these communities in wetlands faces challenges because of the severe anthropogenic impacts that are being generated in both their structure and the services they provide (groundwater recharge, flood water retention, lotic-based flow contributions, biogeochemical processing, water quality improvement, and wildlife habitat) [2, 4], which is leading to its degradation on both local and global scales $[5,6]$.

Global wetland studies have revealed a significant decline of $6 \%$ in just 14 years (1993-2007) due to 
the pressure of rapid urban growth [7]. These changes are limiting water availability and access to this resource. In addition, they motivate the implementation of integrated water management policies [7, 9]. At present, new indices are being generated on the basis of bioindicators using computational methods in order to reduce the intrinsic and subjective uncertainties of environmental problems [10]. However, in order to provide information on the historical state of a body of water and not only on the moment of sampling, multimetric indices have been developed based on communities of macroinvertebrates and benthic algae. The use of benthic fauna to assess the ecological quality of water has become a fundamental factor in integrated water management worldwide [11], allowing for better understanding of the processes of alteration of water quality $[12,13]$.

In Peru, high Andean wetlands remain the least studied and represent one of the most threatened ecosystems. The decline in water quality that these ecosystems have been experiencing due to their inadequate management, despite the fact that they play a fundamental role in human well-being and the maintenance of ecological balance [14], requires a more integrated knowledge of the various processes that occur. Lake Chinchaycocha is located in Junín National Reserve, in the central Andes of Peru at 4090 meters above sea level. In 1997 it was recognized by the Ramsar Convention as a wetland of international importance for being an important habitat for some 20,000 waterbirds, including endemic endangered species such as the Junín grebe (Podiceps taczanowskii), and presenting other groups of wildlife such as the black redfish (Laterallus tuerosii). [15] and the endangered Junin giant frog (Batrachophrynus macrostomus) and native flora of the puna; as well as for the impressive scenic beauty it shows. In this context, and considering that Lake Chinchaycocha is highly contaminated by mining tailings in the northeastern part and sewage discharges from neighboring populated centers [16]. It also plays a transcendental role in the origin of the Mantaro River (the main tributary of the Amazon Basin), which supplies water for the development of agricultural and fishing activities and the generation of electricity [17]. There is a need for tools to monitor the water quality of these ecosystems in order to achieve sustainable wetland management. The objective of the study was to evaluate the behavior of physical-chemical parameters and potentially toxic metals in the surface water of Lake Chinchaycocha using multimeter indices between March and December 2018.

\section{Materials and Methods}

\section{Study Area}

Lake Chinchaycocha is located in Junín National Reserve, in the central Andes of Peru at 4090 meters above sea level. It is the highest lake and the second largest in Peru after Lake Titicaca, with an extension of 34 kilometers long by 16 wide and a depth of 12 meters. Lake Chinchaycocha is mainly fed by the San Juan River, located at the northwest end of the National Reserve and whose average annual discharge is $286,030,000 \mathrm{~m}^{3}$, with maximums of up to $114.7 \mathrm{~m}^{3} / \mathrm{s}$

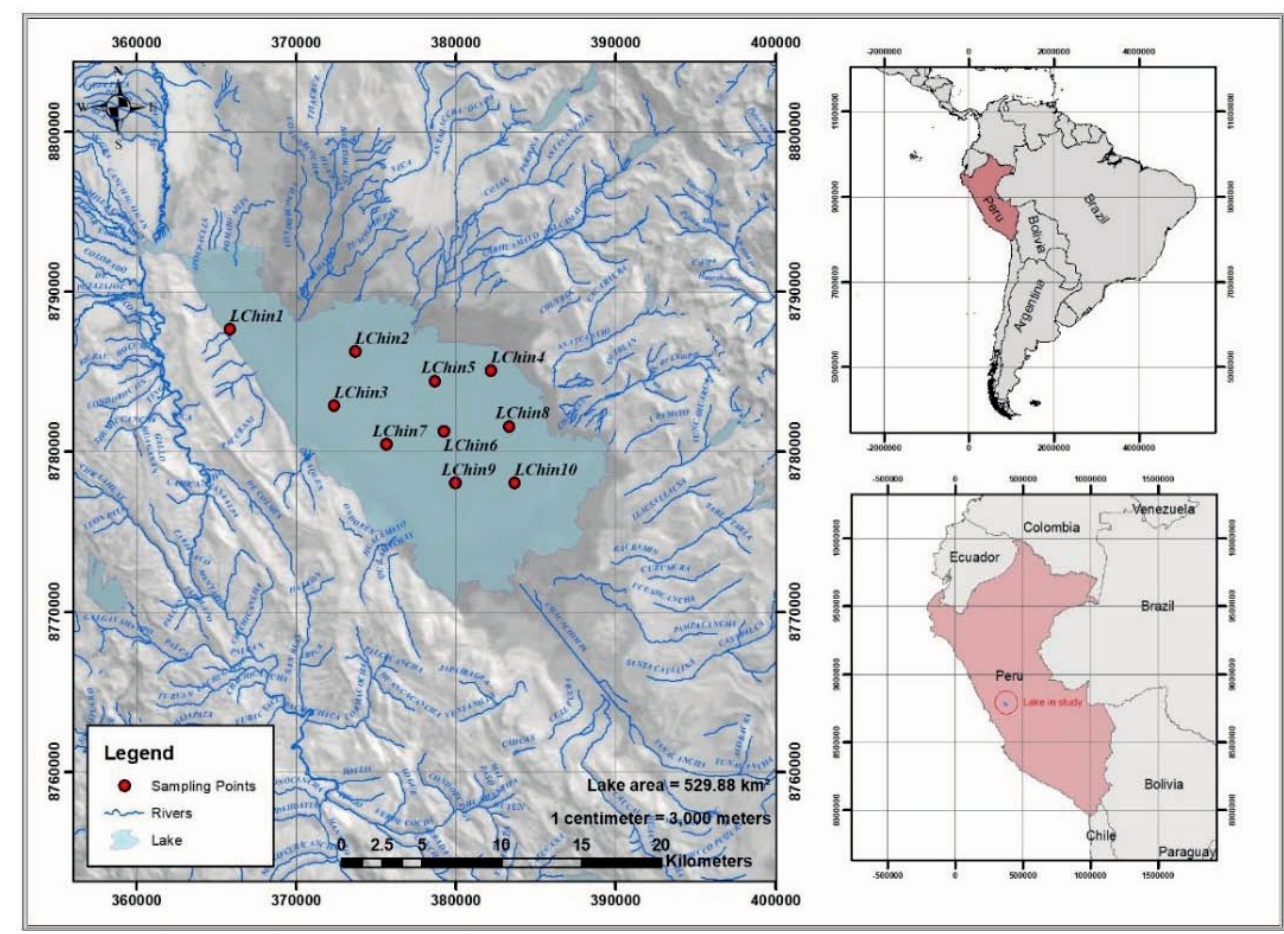

Fig. 1. Location of sampling points in Lake Chinchaycocha, Junín, Peru. 
and minimums as low as $1.01 \mathrm{~m}^{3} / \mathrm{s}$. The lake drains on the northwest side through Upamayo Dam, which started operating in 1936, giving rise to the Mantaro River, which is one of the main Andean tributaries of the Amazon basin [15]. Lake Chinchaycocha forms an important hydrographic system of high productivity and biological diversity (Fig. 1). However, over the years it has experienced strong anthropogenic pressure due to excessive extraction of resources, contamination of water by mining tailings and municipal wastewater, and the generation of electricity [16].

The flora of Lake Chinchaycocha is constituted mainly by totorales that occupy the shores, highlighting the species Scirpus californicus and Juncus articus. Most of them are very dense formations, to such an extent that they are almost impenetrable. The aquatic flora is represented by submerged plants like Myriophyllum, Elodea, Potamogeton, and Utricularia, and some like Chara, Scytonema, Mougeotia, among others; and some floating plants like Lemma, Spirodela and Azolla. To the lake landscape are added the most characteristic associations such as the puna grasslands with grasses of hard and sharp leaves, for example Calamagrostis, Festuca and Stipa; the puna grass formed by species of reduced size $(8-15 \mathrm{~cm})$, in this association are found the grasses of soft leaves, for example Scirpus, Geranium, Werneria, Astragalus and Alchemilla. The best high Andean grasslands are found in this association, and therefore that is where livestock activity is mainly concentrated.

Birds are the most important fauna in Junín National Reserve. Currently, 150 species have been recorded among residents, migratory and occasional, with some 70 species being commonly found throughout the year in the lake. Of the variety of avifauna species present, two critically endangered endemic species (CR) stand out: the Junín Grebe (Podiceps taczanowskii) and the
Junín Gallinetita (Laterallus tuerosii). However, most bird species have suffered a dramatic decline in the number of their populations [15].

\section{Collection and Analysis of Water Samples}

Surface water and sediment samples were collected at 10 inland lake sites during the rainy and dry seasons. The 10 sampling sites were grouped into three sectors. Sector I grouped three sampling sites (LCh1, LCh2 and LCh2) located in the northern part of Lake Chinchaycocha. Sector II grouped four sampling sites (LCh4, LCh5, LCh6 and LCh7) located in the center of the lake. Sector III grouped three sampling sites (LCh8, LCh9 and LCh10) located in the southern part of the lake. The locations of the sampling sectors were recorded using a global positioning system (GPS) device. Water samples were collected $20 \mathrm{~cm}$ from the water surface in two-liter plastic bottles previously treated with a $10 \%$ nitric acid solution for 24 hours and rinsed with double-distilled water. Then $1.5 \mathrm{ml}$ of concentrated nitric acid was added to one litre of water from each of the samples for preservation [18]. For determining $\mathrm{BOD}_{5}$, water samples were collected in amber-colored bottles, previously treated with a solution of hydrochloric acid in a ratio of 1:1 and rinsed with distilled water. The determination of dissolved oxygen, total dissolved solids, conductivity, temperature, $\mathrm{pH}$ and turbidity determined in situ were performed in lenticular and lotic sites of the lake by means of the portable multiparametric equipment of HANNA, model HI 98194.

The physicochemical variables determined in the laboratory were performed using SMEW-APHAAWWA-WEF 5210 B, 22 ${ }^{\text {nd }}$ Ed. 2012 for biochemical oxygen demand (BOD5), SMEW-APHA-AWWA-WEF 5210 D, 22 ${ }^{\text {nd }}$ Ed. 2012 for chemical oxygen demand,

Table 1. Limits of detection and quantification and percentage of recovery of physical-chemical parameters (mg/l).

\begin{tabular}{|c|c|c|c|}
\hline Physical-chemical parameters & Detection limit & Limit of quantification & Percentage of recovery \\
\hline BOD $_{5}$ & 2 & 5 & 97.6 \\
\hline COD & 2 & 5 & 97.6 \\
\hline Total phosphorus & 0.007 & 0.071 & 104.3 \\
\hline Total nitrogen & 0.024 & 5 & 102.0 \\
\hline TSS & 2 & 0.00010 & 101.3 \\
\hline Arsenic & 0.00003 & 0.00002 & 105.1 \\
\hline Cadmium & 0.00001 & 0.0004 & 102.8 \\
\hline Chromium & 0.0001 & 0.00010 & 101.5 \\
\hline Copper & 0.00003 & 0.0020 & 106.0 \\
\hline Iron & 0.0004 & 0.0004 & 107.0 \\
\hline Lead & 0.0002 & 0.0200 & \\
\hline Zinc & 0.0100 & & \\
\hline
\end{tabular}


EPA METHOD 365.3, 1983, total phosphorus, ISO 29441 (validated) for total nitrogen $1^{\text {st }}$. Ed. 2010, a SMEWW-APHA-AWWA-WEF 5210 D, 22 ${ }^{\text {nd }}$ Ed. 2012 for total suspended solids and EPA method 6020A, 2007 for total metals by ICP-MS.

\section{Collection of Sediment and Benthic Macroinvertebrates}

The collection of the surface sediments $(10 \mathrm{~cm}$ deep from the top layer) was carried out in the 10 interior sites of the lake by means of a Hydro-Bios Ekman-Birge dredge. At each sampling site, one-kilogram sediments were sampled to isolate benthic macroinvertebrates. Then $5 \%$ formaldehyde was added to the samples to obtain benthic macroinvertebrates for conservation. The samples were deposited in polyethylene zipper bags and stored at $4^{\circ} \mathrm{C}$. They were then transported to the Water Research Laboratory of the Universidad Nacional del Centro del Perú for their respective taxonomic identification.

\section{Data Analysis}

\section{The Canadian Council of Environment Ministers' Water Quality Index (CCME WQI)}

The WQI CCME consists of three factors, each of which has been scaled between 0 and 100. The values of the three measures of variance of the selected water quality targets are combined to create a vector in an imaginary space of "objective overcoming". In the index, the "targets" refer to Canada-wide water quality guidelines or site-specific water quality targets [19].

The length of the vector is scaled to a range between 0 and 100, and subtract from 100 to produce an index that is 0 (or close to 0 ) for very poor water quality, and about 100 for excellent water quality. The CCME WQI consists of three factors, as shown in the Fig. 2.
Factor 1 (F1) - Scope: Evaluates the degree of noncompliance with the water quality guideline during the period of interest.

Factor 2 (F2) - Frequency: Represents the percentage of individual tests that do not meet the targets ("failed tests").

Factor 3 (F3) - Amplitude: Represents the amount by which failed test values do not meet their targets, and is calculated as:

$$
\text { CCME WQI }=100-\left[\frac{\sqrt{\left(\mathrm{F}_{1}\right)^{2}+\left(\mathrm{F}_{2}\right)^{2}+\left(\mathrm{F}_{3}\right)^{2}}}{1.732}\right]
$$

The WQI CCME scores were grouped into 5 categories of water quality: poor (0-44), marginal (45-64), regular (65-79), good (80-94) and excellent (95-100) (CCME, 2007). Previously, water quality index scores were determined for 16 physical-chemical indicators.

\section{Shannon-Wiener Diversity Index (H')}

The H' index measures the information content per individual in randomly collected samples from a given community with a total number of $\mathrm{S}$ species. In addition, as a measure of uncertainty, it makes it possible to predict to which species an individual randomly selected from a sample of $\mathrm{S}$ species and $\mathrm{N}$ individuals will belong [21]. Therefore, $\mathrm{H}^{\prime}=0$ when the sample contains only one species, and H' will be maximum when all species $\mathrm{S}$ are represented by the same number of individuals $n$ i.

$$
\mathrm{H}^{\prime}=\sum_{i=1}^{S} \text { pi ln pi }
$$

...where Pi is total proportion of the sample belonging to species "I", with $\mathrm{i}=1,2 \ldots \mathrm{S}$; where "S" is the total number of species present in the sample.

The maximum value it acquires in aquatic ecosystems for benthic macroinvertebrate communities is 4.5. Values lower than 2.4-2.5 indicate that the system is under stress (discharge, dredging, channelling,

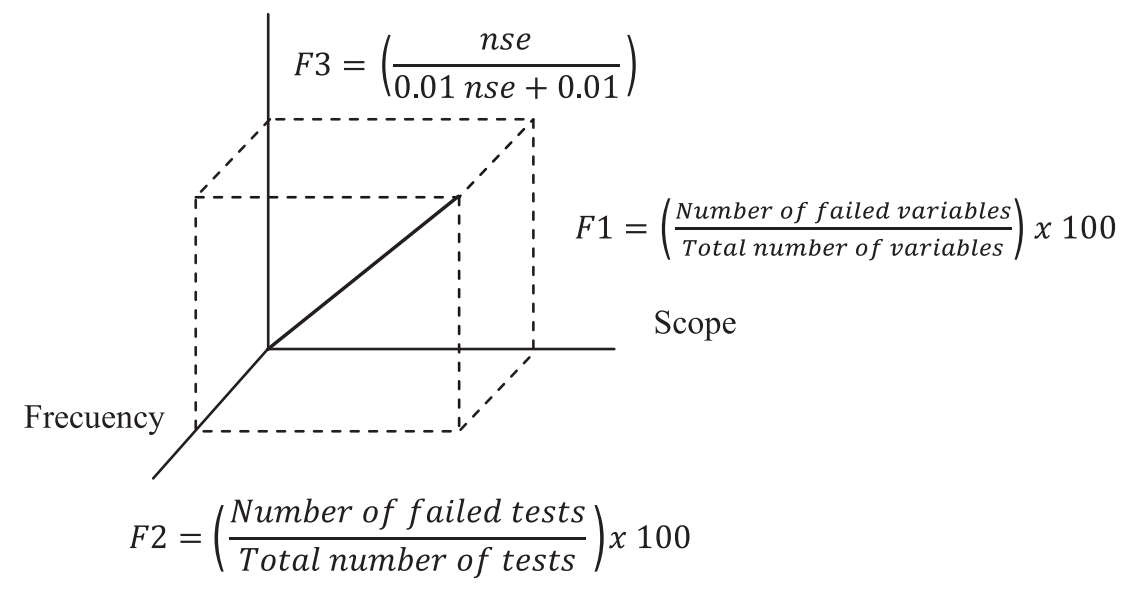

Fig. 2. Three-dimensional representation of the water quality index by adding three factors (F1, F2 and F3) as vectors [20]. 
regulation by reservoirs, etc.). It is an index that decreases a lot in very polluted waters. Therefore, the higher the value of the Shannon-Wiener index, the higher the quality of the water under study.

\section{Statistical Analysis}

A cluster analysis of the physical-chemical indicators of water quality was performed using normalized data using the Ward method, using Euclidean distances as a measure of similarity [22] to assess spatial and temporal variations; as well as to detect and group similar sampling sites.

Principal component analysis was used to identify important water quality indicators and to investigate possible sources of heavy metals in the aquatic environment. The physical-chemical indicators used in the determination of the water quality index were used to validate the results obtained through the analysis of main components in order to extract new axes of variation that summarize the variability of the sampling sites and the physical-chemical variables of the water.

\section{Results}

\section{Water Quality Analyzed by Means of Multimetric Indices}

Table 2 shows the descriptive statistics of the physical-chemical indicators of water quality in Lake Chinchaycocha, considering the sector and climatic sampling period. The $\mathrm{pH}$ of the water showed variations in each of the evaluated sectors, with average values ranging from 8.437 in sector I during the low-water period to 8.82 in sector III during the rainy season. However, the highest $\mathrm{pH}$ value was recorded in sector I. The variations of the $\mathrm{pH}$ registered in the sampling sectors are within the natural ranges for the conservation of the lacustrine aquatic environment (6.5-9.0) and recreation (6.0-9.0), according to the environmental quality standards for water (EQS-water) of the Ministry of the Environment of Peru [23]. As well as within the ranks established by the Canadian Council of Ministers of the Environment [24] for aquatic life. However, in most sampling sites the $\mathrm{pH}$ values exceed the range of water intended for drinking water production (6.5-8.5), both the environmental quality standards for water (EQS-water) of Peru and the World Health Organization (WHO) [25]. The value of electrical conductivity (EC) in water samples ranged from 270.70 to $299.90 \mu \mathrm{S} / \mathrm{cm}$. The lowest mean EC value was recorded in sector I of the lake $(262.31 \mu \mathrm{S} / \mathrm{cm})$; this reveals that in this sector the concentration of dissolved ions and organic matter is lower than in the other sampling sites in sectors I and II. The recommended value of $\mathrm{EC}$ for the conservation of the aquatic environment according to the EQS-water of Peru is $1000 \mu \mathrm{S} / \mathrm{cm}$.
The mean values of the chemical demand for oxygen-COD did not exceed the category 3 EQS-water $(40 \mathrm{mg} / \mathrm{L})$ intended for vegetable irrigation and animal drinking. The mean $\mathrm{BOD}_{5}$ values recorded in the three sampling sectors did not exceed the EQS-water $(5 \mathrm{mg} / \mathrm{L})$ intended for the conservation of the aquatic environment. However, at one of the sector I sampling sites, $\mathrm{BOD}_{5}$ exceeded the EQS-water. Dissolved Oxygen-DO concentrations recorded in the three sampling sectors of Lake Chinchaycocha are in the range of the EQS-water of Peru and of the World Health Organization (5.5-9.5 mg/1). Average temperature values ranged from $11.69^{\circ} \mathrm{C}$ in sector $\mathrm{I}$ in the dry season to $13.52^{\circ} \mathrm{C}$ in sector II in the rainy season. The total suspended solids values at all sampling sites in the three sectors did not exceed the EQS-water. The mean total phosphorus values were higher than the Peruvian EQS-water $(0.035 \mathrm{mg} / \mathrm{L})$, in all the sampling sites of sectors I and II of the lake, where the concentrations of this nutrient are three times higher than the EQSwater. The mean values of total nitrogen recorded in the two climatic periods far exceeded the EQS-water $(0.315 \mathrm{mg} / \mathrm{L})$, with the highest value recorded in sector I during the low-water period.

The mean values of the heavy metals recorded in the water samples varied according to sector and climatic sampling period. In sector I, metals were in the descending order of $\mathrm{Fe}>\mathrm{Cu}>\mathrm{Zn}>\mathrm{Pb}>\mathrm{Cr}>\mathrm{Cd}>\mathrm{As}$. In sectors II and III the trend of availability of metals was similar, although at lower concentrations. The mean and maximum values of the evaluated heavy metals (except $\mathrm{Pb}$ ) were lower than the Peruvian EQS-water. The highest values of $\mathrm{Pb}$ were recorded in the sector I sampling sites in the low-water period.

The results of the Chinchaycocha Lake water quality assessment based on the CCME- WQI at all sampling sites rated the water as good, except for the LCh1 sector I sampling site in the climate low water period, which rated the water as marginal. These results corroborate the results obtained by indicators in the three sampling sectors (Table 3). It also confirms the strong anthropogenic pressure that the lake has been supporting in sector I (northern part of the lake) - an area adjacent to Upamayo Dam.

The water quality results evaluated in terms of the structure of benthic macroinvertebrate communities using the Shannon-Wiener index showed low benthic fauna diversity indices. The highest abundance was recorded in sector II, specifically at the LCh5 sampling sites in both the rainy and low-water periods. The highest diversity was recorded in sector $\mathrm{I}$, at sites LCh2, LCh4, LCh8 and LCh10 (H': 2.019, 2.085, 2.017 and 2.066; respectively) in the rainy season; and in sector III at LCh8 (H': 2.176) in the dry season. However, in terms of water quality the results classify this body of water as a polluted aquatic environment, with disturbances ranging from moderately polluted to extremely polluted. The LCh1 and LCh9 sites have the lowest diversity values ( $\mathrm{H}^{\prime}: 0.640$ and 0.666 ; 


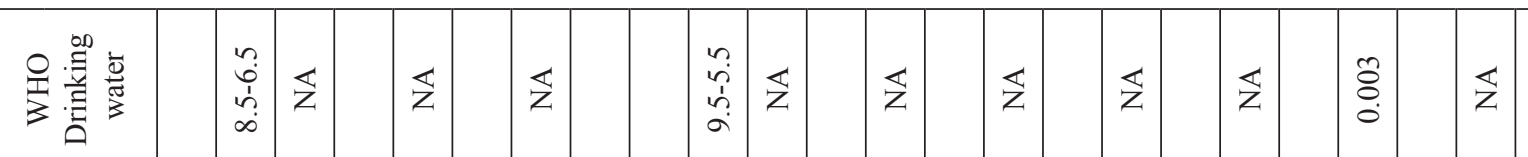

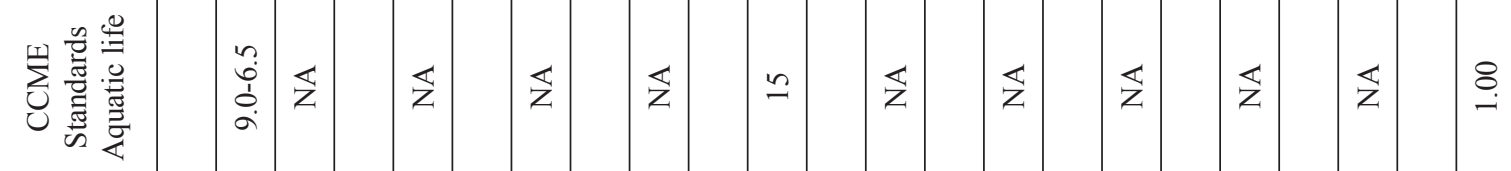

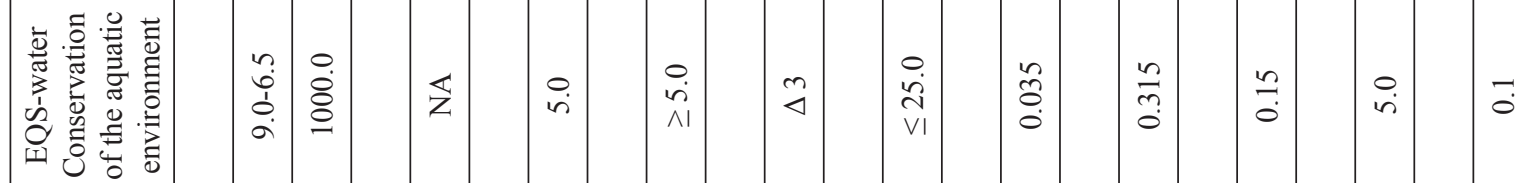

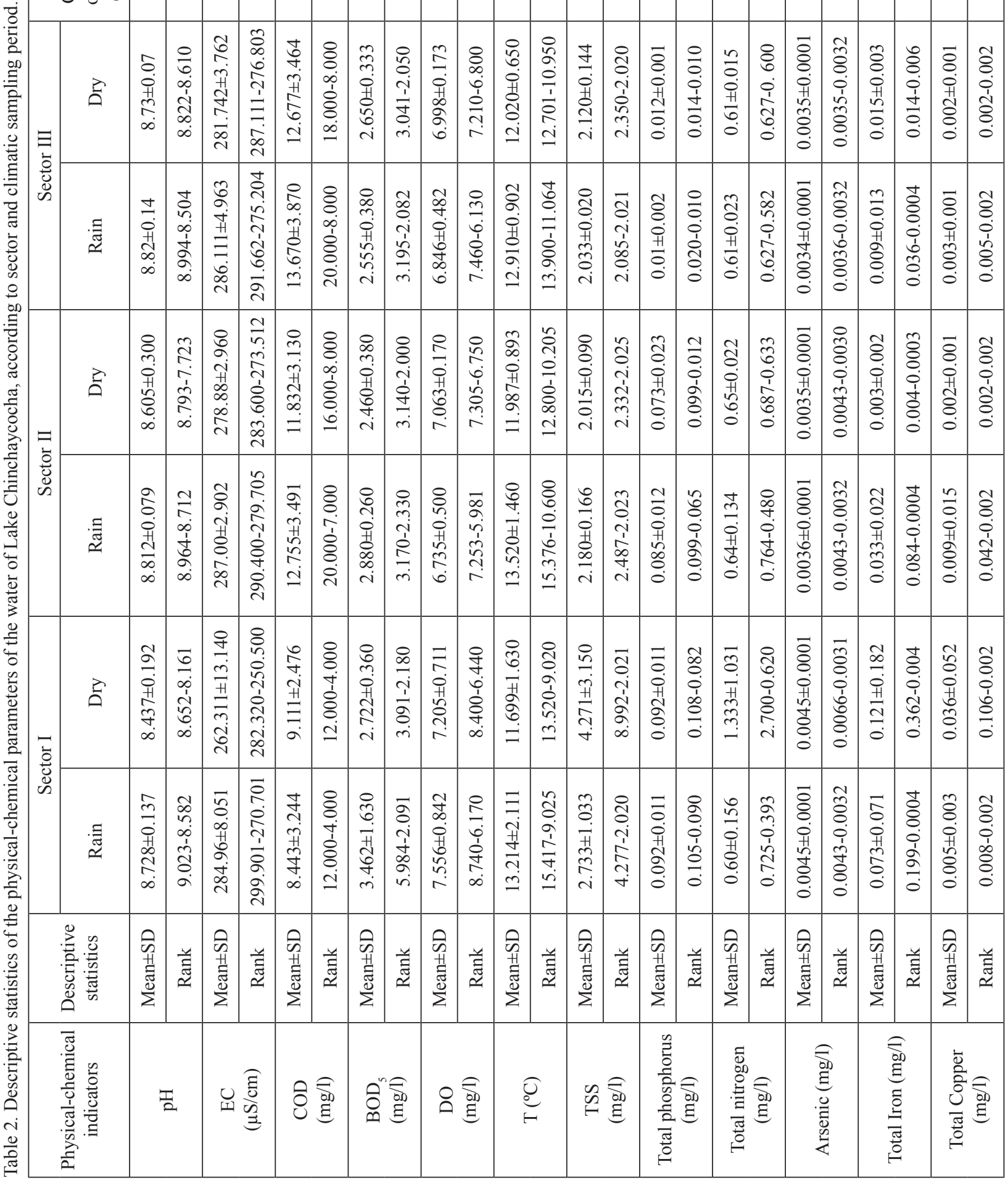




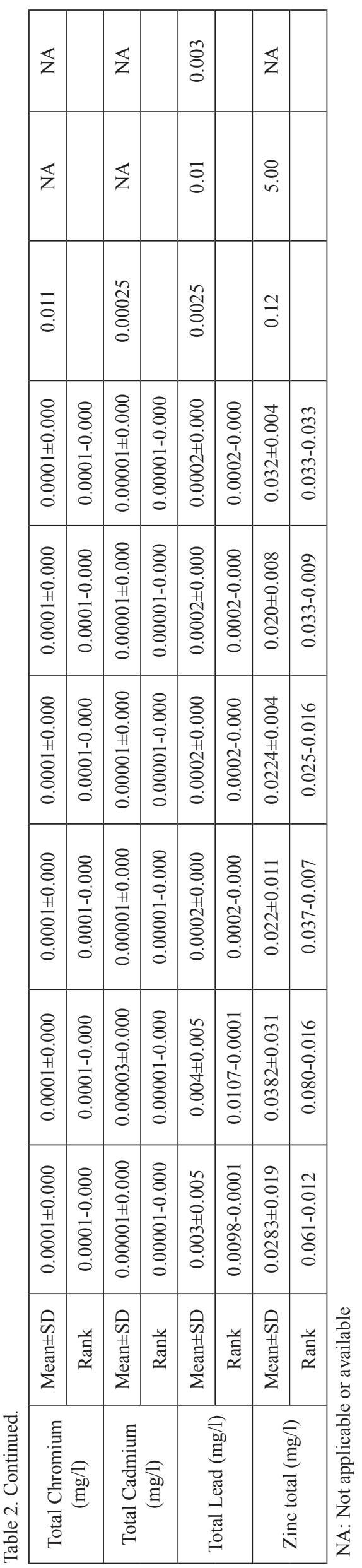

respectively) compared to the other sampling sites (Table 4).

\section{Spatial Similarity of Sampling Sites}

The cluster analysis processed a dendogram that grouped the sampling sites into two clusters with similar characteristics (Fig. 3). The main factors used in the analysis were the sites and the sampling period. The results of this study also reveal that anthropogenic disturbances occur along the lake. The first cluster made up of the LCh1 sampling site is influenced by mining activities focused on sector I. The second grouping consists of the remaining sampling sites influenced by nearby anthropogenic activities. The analysis also shows that there is a large separation of the LCh1 sampling site for both the rainy and low-water periods, as this area would be disturbed by mining tailings. In addition, the separation of these two groups occurs at a temporal level; there is a clear difference between their physical-chemical values in relation to the climatological season found.

\section{Analysis of Main Components}

The analysis of main components (PCA) of the physical-chemical indicators and the sampling sites is presented in Fig. 4. The percentage of total variation of the observations of the three main axes was $76.07 \%$, which indicates that the distribution of the data obeys particular physical-chemical characteristics and that its interpretation is very close to the real observation taking into account the main axes. The perceptual map shows that the distance established by the factors: climate period and sampling site is marked. The LCh1 site, both in the dry period and in the rainy period, shows a clear distance from the other sites. This would indicate that this site has significant differences in relation to the other physical-chemical indicators.

The first two components accounted for $63.6 \%$ of the accumulated variability. Component 1 was closely related to total suspended solids, nitrates, iron, copper, zinc and arsenic, due to the discharge of the San Juan River from areas with mining influence that flow near the LCh1 site. Component 2 revealed that LCh1 changes its values in relation to the climatic period and differs from the other sites. The variables related to this component were $\mathrm{pH}$, temperature, COD, chromium, cadmium and lead. Likewise, the results of the distance from the paired sample in the dry season indicated that the increase in precipitation reduces the values of the variables of the first component (Fig. 4). 
Table 3. Water quality of Lake Chinchaycocha according to the water quality index of the Canadian Council of Environment Ministers CCME-WQI.

\begin{tabular}{|c|c|c|c|c|c|c|c|}
\hline Climate period & Sampling Sector & Sampling site & $\mathrm{F} 1$ & F2 & F3 & CCME-WQI & WQI according to colour \\
\hline \multirow{10}{*}{ Rain } & \multirow{3}{*}{ I } & LCh1 & 12.50 & 12.50 & 1.96 & 89.73 & Good \\
\hline & & LCh2 & 6.25 & 6.25 & 7.41 & 93.34 & Good \\
\hline & & LCh3 & 6.25 & 6.25 & 9.09 & 92.68 & Good \\
\hline & \multirow{4}{*}{ II } & LCh4 & 6.25 & 6.25 & 2.91 & 94.62 & Good \\
\hline & & LCh5 & 6.25 & 6.25 & 7.41 & 93.34 & Good \\
\hline & & LCh6 & 6.25 & 6.25 & 7.41 & 94.62 & Good \\
\hline & & $\mathrm{LCh} 7$ & 6.25 & 6.25 & 5.66 & 93.94 & Good \\
\hline & \multirow{3}{*}{ III } & LCh8 & 6.25 & 6.25 & 5.66 & 93.94 & Good \\
\hline & & LCh9 & 6.25 & 6.25 & 4.76 & 94.20 & Good \\
\hline & & LCh10 & 6.25 & 6.25 & 4.76 & 94.20 & Good \\
\hline \multirow{10}{*}{ Dry } & \multirow{3}{*}{ I } & LCh1 & 12.5 & 12.5 & 70.46 & 58.06 & Marginal \\
\hline & & LCh2 & 6.25 & 6.25 & 5.85 & 90.42 & Good \\
\hline & & LCh3 & 6.25 & 6.25 & 6.54 & 93.65 & Good \\
\hline & \multirow{4}{*}{ II } & LCh4 & 6.25 & 6.25 & 6.08 & 93.81 & Good \\
\hline & & LCh5 & 6.25 & 6.25 & 6.17 & 93.59 & Good \\
\hline & & LCh6 & 6.25 & 6.25 & 6.73 & 93.78 & Good \\
\hline & & LCh7 & 6.25 & 6.25 & 5.94 & 93.85 & Good \\
\hline & \multirow{3}{*}{ III } & LCh8 & 6.25 & 6.25 & 5.81 & 93.89 & Good \\
\hline & & LCh9 & 6.25 & 6.25 & 5.66 & 93.94 & Good \\
\hline & & LCh10 & 6.25 & 6.25 & 5.33 & 94.04 & Good \\
\hline
\end{tabular}

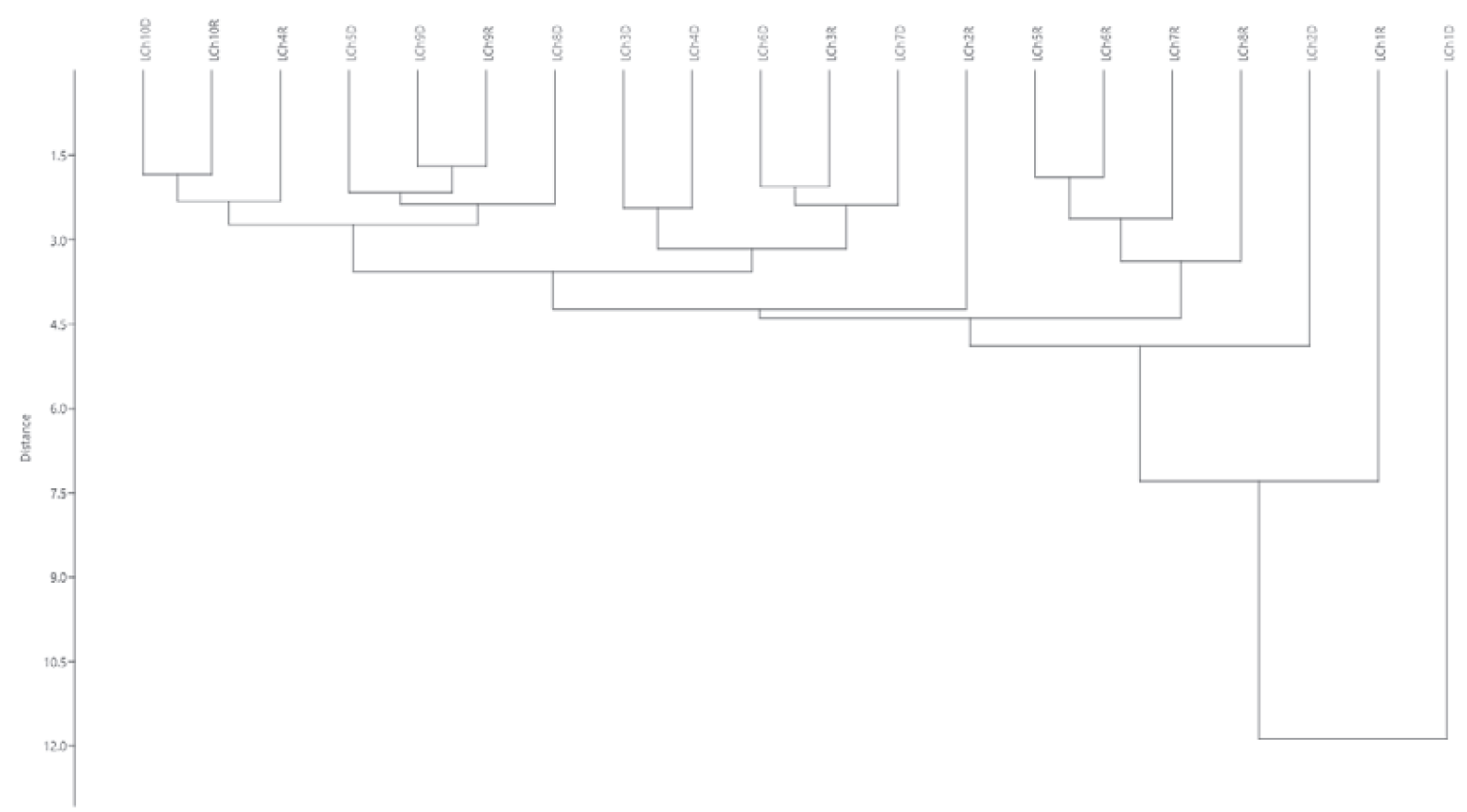

Fig. 3. Dendogram of the cluster analysis for the sampling sites of Lake Chinchaycocha according to the physical-chemical indicators of water quality. 


\begin{tabular}{|c|c|c|c|c|c|c|c|c|c|c|c|c|c|c|c|c|}
\hline \multirow{10}{*}{ 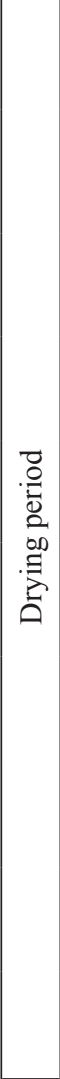 } & \multirow{3}{*}{$\begin{array}{l}B \\
0 \\
0 \\
0 \\
0\end{array}$} & 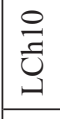 & + & 0 & ‡ & $\stackrel{\infty}{\curvearrowright}$ & 0 & 2 & $\sigma$ & 0 & 0 & $\tilde{I}$ & $\nabla$ & $\frac{n}{2}$ & 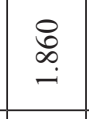 & 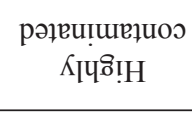 \\
\hline & & ड्తे & 0 & 0 & 0 & $\grave{\lambda}$ & 0 & $r$ & 0 & 0 & 0 & 0 & 0 & 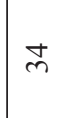 & : & $\begin{array}{c}\text { рәұеи!шеұшо } \\
\text { Крәшәлхв }\end{array}$ \\
\hline & & 离 & $m$ & 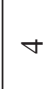 & $\stackrel{8}{0}$ & $\simeq$ & $\simeq$ & లు & $N$ & $N$ & in & f & 0 & $\underset{\sim}{\stackrel{D}{\sim}}$ & $\stackrel{\circ}{\stackrel{2}{i}}$ & 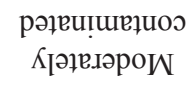 \\
\hline & \multirow{7}{*}{$\begin{array}{l}0 \\
0 \\
0 \\
0\end{array}$} & 氖 & 0 & 0 & $\stackrel{ \pm}{\sim}$ & $\infty$ & $\cong$ & $\stackrel{\infty}{\rightarrow}$ & 0 & 0 & 0 & 0 & 0 & లె & $\stackrel{n}{m}$ & 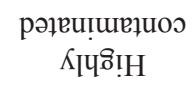 \\
\hline & & $\begin{array}{l}0 \\
\text { J্ } \\
\end{array}$ & 0 & 0 & $\overline{\vec{v}}$ & is & 0 & 0 & $\underline{ح}$ & 0 & 0 & 0 & 0 & & हิ & 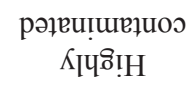 \\
\hline & & 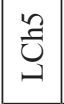 & 0 & 0 & ర్ల & $\vec{\infty}$ & 0 & 0 & $r$ & 0 & $=$ & $\simeq$ & 0 & $\vec{q}$ & $\stackrel{?}{\stackrel{2}{2}}$ & 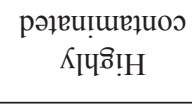 \\
\hline & & $\begin{array}{l} \pm \\
\text { J } \\
\end{array}$ & $\infty$ & $m$ & 点 & $\infty$ & $\approx$ & $N$ & 0 & 0 & 0 & ले & $r$ & ָั & ڤે & 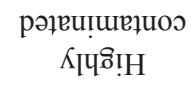 \\
\hline & & $\begin{array}{l}\Re \\
\text { J్త } \\
\end{array}$ & 0 & 0 & $F$ & y & ते & $\stackrel{0}{0}$ & $r$ & 0 & 0 & $\stackrel{\infty}{\sim}$ & 0 & : & 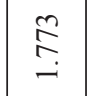 & 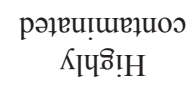 \\
\hline & & כี & 0 & 0 & fo & $\Xi$ & $=$ & $\bar{\imath}$ & $N$ & 0 & 0 & $=$ & 0 & స్ & $\stackrel{n}{i}$ & 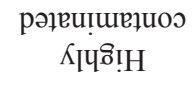 \\
\hline & & \begin{tabular}{|l}
$\vec{E}$ \\
\\
\end{tabular} & 0 & 0 & $\Xi$ & $m$ & 0 & 0 & 0 & 0 & 0 & 0 & 0 & $=$ & : & 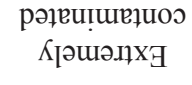 \\
\hline \multirow{10}{*}{ 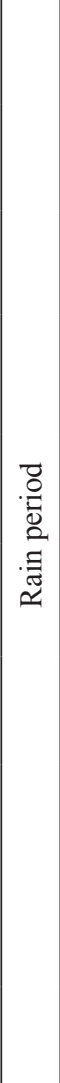 } & \multirow{7}{*}{ 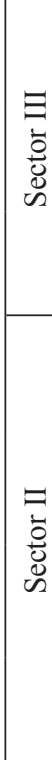 } & 号 & $\sim$ & $N$ & $\stackrel{\infty}{\varrho}$ & $\alpha$ & 0 & ○ & 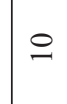 & $m$ & 0 & $=$ & $\nabla$ & 点 & 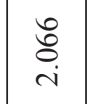 & 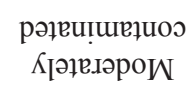 \\
\hline & & ड્తి & 0 & 0 & $\stackrel{2}{2}$ & సి & 0 & $a$ & 0 & 0 & 0 & 0 & 0 & $\stackrel{\infty}{0}$ & $\stackrel{t}{\stackrel{t}{0}}$ & 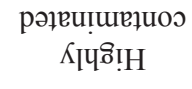 \\
\hline & & 足 & $N$ & 0 & $\kappa$ & $=$ & \pm & $\Xi$ & $\because$ & 0 & 0 & 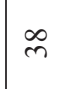 & 0 & Әे & $\stackrel{\tilde{\sigma}}{\text { i }}$ & 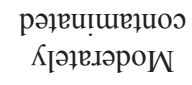 \\
\hline & & 氖 & 0 & 0 & $\Xi$ & $\vec{\infty}$ & $\stackrel{\infty}{\stackrel{0}{2}}$ & $\stackrel{\infty}{\longrightarrow}$ & 0 & 0 & 0 & 0 & 0 & $\underset{\sim}{\sim}$ & 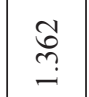 & 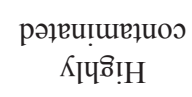 \\
\hline & & 号 & 0 & 0 & $\stackrel{0}{\sim}$ & in & $\nabla$ & $\sigma$ & 0 & 0 & 0 & 0 & 0 & $\stackrel{\infty}{\stackrel{\infty}{v}}$ & $\stackrel{\overbrace{}}{\stackrel{n}{\sim}}$ & 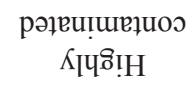 \\
\hline & & 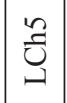 & - & 0 & $\underset{m}{\stackrel{f}{*}}$ & $\Phi$ & $\nabla$ & 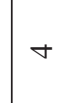 & $\Xi$ & 0 & 0 & 0 & 0 & $\overrightarrow{⿱ n}+$ & ?ִ & 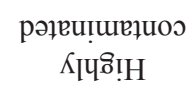 \\
\hline & & 莺 & $N$ & $N$ & సి & $\stackrel{\infty}{\infty}$ & 9 & 9 & 0 & 0 & $\simeq$ & D & $a$ & $\stackrel{\infty}{\text { m }}$ & $\stackrel{\infty}{o}$ & 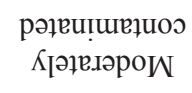 \\
\hline & & 胥 & 0 & $\nabla$ & $\hat{\imath}$ & $\bar{F}$ & $\tilde{\pi}$ & ה & 0 & 0 & 0 & $\tilde{N}$ & 0 & $\exists$ & $\stackrel{2}{a}$ & 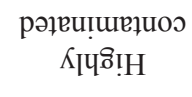 \\
\hline & $\begin{array}{l}\overrightarrow{\tilde{a}} \\
\overline{0} \\
\tilde{c}\end{array}$ & ปี & 0 & $N$ & ले & $\infty$ & 0 & 0 & $r$ & 0 & 0 & i & $=$ & 穴 & $\stackrel{\vec{\partial}}{i}$ & 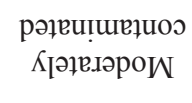 \\
\hline & & 苟 & 0 & 0 & $\simeq$ & $\infty$ & $a$ & $a$ & 0 & 0 & 0 & 0 & 0 & $\underset{\sim}{\infty}$ & $\stackrel{n}{\infty}$ & 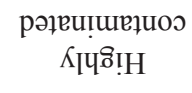 \\
\hline & 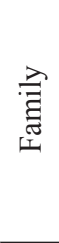 & & 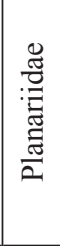 & 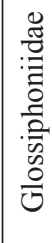 & 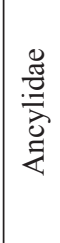 & 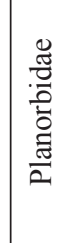 & 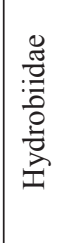 & 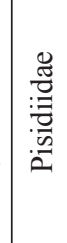 & 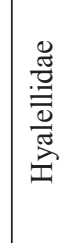 & 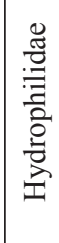 & $\begin{array}{l}\text { 㺃 } \\
\text { 帛 } \\
\end{array}$ & 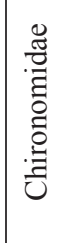 & 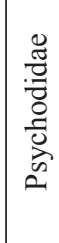 & 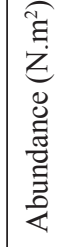 & 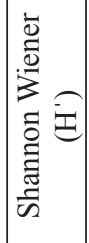 & 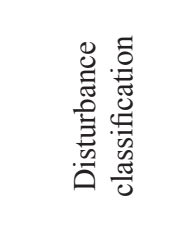 \\
\hline
\end{tabular}




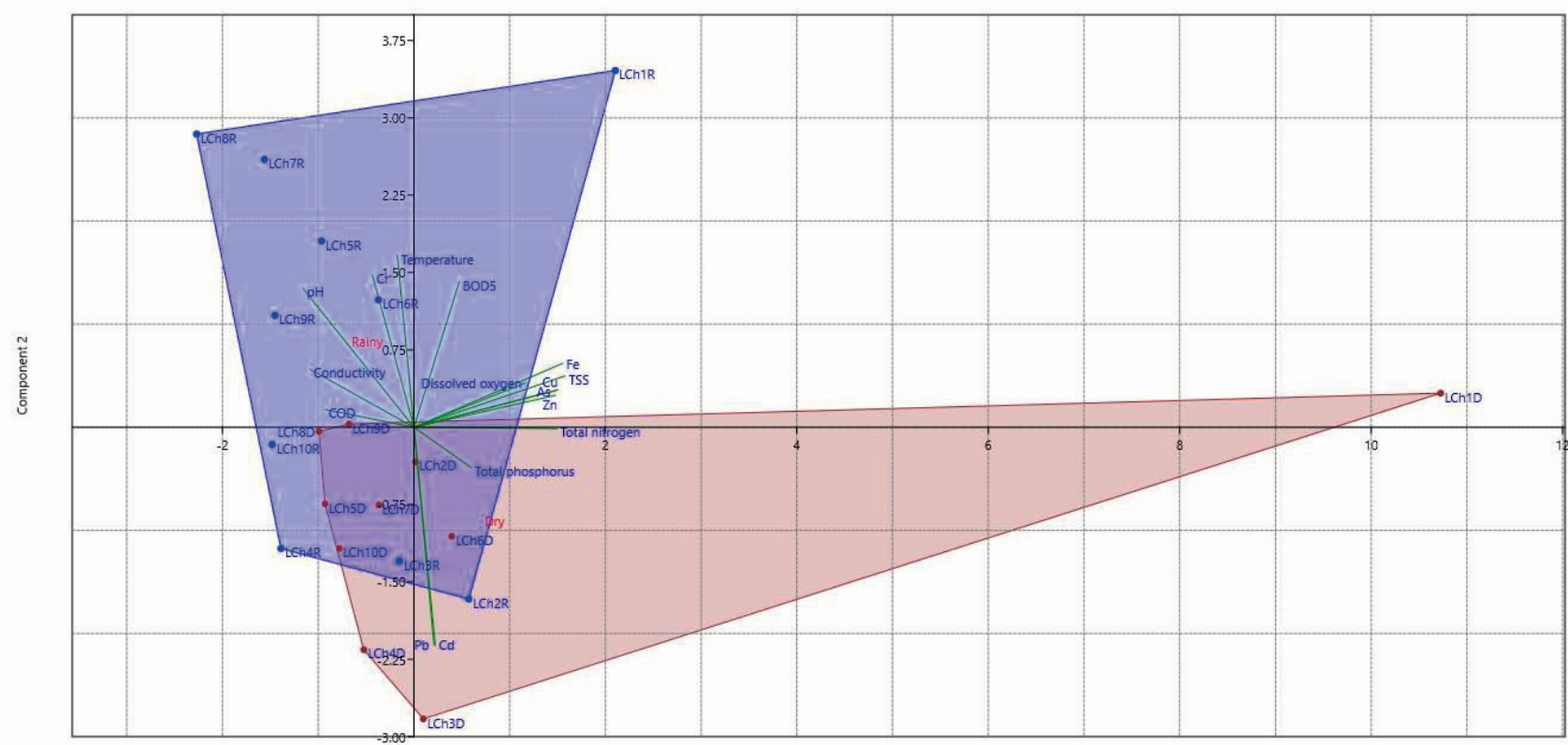

Component 1

Fig. 4. Analysis of the main components of the sampling sites of Lake Chinchaycocha, based on the physical-chemical indicators of the water.

\section{Discussion}

\section{Water Quality Analyzed by Means of Multimetric Indices}

Water is the renewable natural resource that exerts the most limiting action on human development and on all forms of life. Its demand for different uses has intensified in recent decades, affecting the quantity, quality and timeliness of the flows of this resource. The water $\mathrm{pH}$ results obtained during the two climatic sampling periods are in the range of the EQSwater, intended for the conservation of the aquatic environment of lagoons and lakes. [23]. These results would be influenced by soil conditions, agrochemicals and municipal and industrial dumping. Otro factor determinante de la variabilidad del $\mathrm{pH}$ del agua serían los proceso fotosintéticos que ocurren durante la fase luminosa $[24,25]$.

The highest average EC values were recorded for sectors II and III during the rainy season, which is due to the presence of ions and anions that are concentrated by the effect of evaporation and degradation processes of organic matter. The EC recorded in sectors II and III in the rainy season is due to the influence of temperature; since at high temperature water is lost by evaporation, resulting in the concentration of dissolved ions [28]. Another factor that would be influencing this is the flow of runoff water from agricultural areas adjacent to the lake. Dissolved oxygen (DO) and temperature are important factors in assessing the suitability of water for aquatic life and the distribution of biological communities [29]. According to Peruvian law, maintaining good water quality in lagoons and lakes requires DO values $\geq 5 \mathrm{mg} / \mathrm{L}$ (MINEN, 2017). The average concentration of DO recorded in the study area is evidence of the interactive phenomena of this gas with the atmosphere and the chemical and biological processes that occur in the aquatic environment [30]. The mean values of $\mathrm{COD}$ and $\mathrm{BOD}_{5}$ recorded in the three sampling sectors showed variations between the different sites, which would be related to agricultural activities and wastewater discharges by the surrounding peasant communities. Temperature is also essential in the aquatic environment, since it intervenes in different physical-chemical phenomena, such as oxygen dissolution and biological reactions [31]. The data recorded in the sectors evaluated showed a uniform temperature.

The mean TSS values in the three sampling sectors did not exceed the EQS-water, which reveals the influence of the hydrological cycle on the lake. Phosphorus together with nitrogen are nutrients that influence the trophic state of the water body, so their use as indicators of anthropogenic pressure can detect eutrophication problems [32]. The mean values obtained for total phosphorus in sectors I and II evaluated exceed the EQS-water $(0.035 \mathrm{mg} / \mathrm{L})$, intended for the conservation of the aquatic environment. These results reveal the pollution problems that the lake has been experiencing due to the high supply of nutrients through the discharge of wastewater from mining activities, the use of fertilizers and livestock activities. Average total nitrogen values far exceeded the EQS-water in all sectors assessed.

In general, the space-time variations of As and heavy metals in water bodies depend on several factors, such as: weather, climate, soil type, $\mathrm{pH}$, redox potential 
and dilution capacity [33]. In sector I, the LCh1 site presented high average values of $\mathrm{Pb}$ that surpassed Peru's EQS-water [23], the standards of the Canadian Council of Ministers of the Environment and the standards of the World Health Organization [25] during rainy periods, which is mainly due to mining activity in the area, whose wastewater discharge directly into tributary rivers without trapping $\mathrm{Pb}$. However, domestic and industrial wastewater discharge would also contribute to the increase of this metal, since the peasant communities and urban areas surrounding the lake do not have an adequate wastewater treatment system. The other metals were found in the range of the standards of conservation of the aquatic environment, aquatic life and production of drinking water.

$\mathrm{Pb}$ is a heavy metal found as metallic lead, inorganic and organometallic compounds. In nature, it is found in its tetravalent and divalent forms, with $\mathrm{Pb}^{2+}$ predominant over $\mathrm{Pb}^{4+}$. However, the compounds that this metal forms as the salt of $\mathrm{Pb} 2+$ in high concentrations in the aquatic environment is toxic to most life forms [34]. Fe is the fourth most abundant heavy metal in the earth's crust and is also present in natural waters. In water $\mathrm{Fe}$ is mainly controlled by flow conditions, $\mathrm{pH}$, redox potential, and the type and amount of dissolved organic matter [35]. Its concentration was found in the range of national and international standards. However, at high concentrations this metal affects the diversity and abundance of aquatic species, such as macroinvertebrates, perifiton and fish [36]. $\mathrm{Cu}$ is present in the earth's crust with a composition of $50 \mathrm{mg} / \mathrm{L}$. The recorded values were in the range of national and international water quality standards. On the other hand, $\mathrm{Cd}$ also exists naturally in the earth's crust. In addition, anthropogenic activities such as improper handling of $\mathrm{Ni}-\mathrm{Cd}$ batteries, industrial activities, and agricultural activities constitute sources of $\mathrm{Cd}$ loading in aquatic environments [37]. Inorganic As is considered the most toxic to human health. At low doses over a long period of time it causes skin changes that can lead to skin cancer [38].

In general, the heavy metals $(\mathrm{Fe}, \mathrm{Cu}, \mathrm{Cr}, \mathrm{Cd}$ and $\mathrm{Zn})$ and $\mathrm{As}$ in the present study had relatively low concentrations compared to the results obtained by Monroy, Maceda-Veiga and de Sostoa [39] in the study on concentrations of heavy metals in water, sediment and fish from Lake Titicaca, Peru (the world's highest lake) showing that all contaminated sites had a degree of metal contamination (e.g., $\mathrm{Cu}, \mathrm{Zn}, \mathrm{Pb}, \mathrm{Co}$ ). In Peru, Lake Chinchaycocha, which is the subject of this study, is the second largest lake after Titicaca, and studies of this nature are scarce in these bodies of water; for this reason, it is urgent to integrate efforts in order to reduce the uncertainty of the health status of these ecosystems.

Water quality indices are very useful tools for communicating information on water quality to both the authorities and the general public. You can quickly give us a general picture of the state of the water resource. It is very useful for comparative purposes, and to determine which sampling points have the worst water quality [40]. The WQI CCME applied for water quality assessment revealed that the lake has good water quality at all sampling sites, except LCh1, which rated marginal water quality, reflecting fluctuating water quality due to combinations of anthropogenic and natural activities.

The water quality evaluated according to the structure of the benthic macroinvertebrate communities using the Shannon-Wiener index shows low indices of diversity of benthic fauna qualifying as a polluted aquatic environment, with disturbances ranging from moderately polluted to extremely polluted. These results are corroborated by the PCA, which reveals that the LCh1 site, both in low water and during the rainy season, shows a clear distance from the other sites. This would indicate that this site has significant differences in relation to the others with respect to the physicalchemical indicators. They are also consistent with the results of other authors who have used PCA for surface and groundwater quality investigations in order to characterize the nature of water quality deterioration [39-41].

\section{Conclusions}

This study used multimetric indices to evaluate the behavior of physicochemical parameters and potentially toxic metals in the surface water of Lake Chinchaycocha. Various multivariate indices and techniques are adopted to evaluate temporal and spatial variations in water quality. The WQI CCME rated all sampling sites in the low-water period as water of good quality, except LCh1 of sector I, which qualified as water of marginal quality. The results of the water quality evaluated according to the structure of the benthic macroinvertebrate communities using the Shannon-Wiener index showed low indices of benthic fauna diversity, qualifying this body of water for being moderately and extremely contaminated. The cluster analysis grouped the sampling sites into two clusters with similar characteristics. The first cluster is the LCh1 sampling site, which is influenced by mining activities focused on sector I. The second grouping consists of the remaining sampling sites influenced by nearby anthropogenic activities. In the analysis of main components, the percentage of total variation of the observations of the three main axes was $76.07 \%$, which reveals that the distribution of the data obeys particular physical-chemical characteristics and that its interpretation is very close to the real observation taking into account the main axes. In addition, the results of this study demonstrate the great usefulness of multivariate statistical techniques to identify sources of contamination, explain the temporal behavior of physical-chemical parameters and support water quality results obtained through conventional water quality indices. 


\section{Acknowledgements}

The authors express our gratitude to the General Research Institute of the Universidad Nacional del Centro del Perú for the financing of the study, to the Water Research Laboratory for allowing us to make use of the equipment and materials for this study.

\section{Conflict of Interest}

The authors declare that they have no conflict of interest.

\section{References}

1. ŽIVKOVIĆ N., TAKIĆ L., DJORJEVIĆ L. DJORJDJEVI A., MLADENOVIĆ-RANISAVLJEVIĆ I., GOLUBOVIĆ T. BOZILOV A. Concentrations of Heavy Metal Cations and a Health Risk Assessment of Sediments and River Surface Water: A Case Study from a Serbian Mine, Polish J. Environ. Stud., 28 (3), 2009, 2018.

2. COOPER M.J., UZARSKI D.G. Invertebrates in Freshwater Wetlands in Invertebrates in Freshwater Wetlands, 287, 2016.

3. IWASAKI Y.S., ORMEROD J. Estimating safe concentrations of trace metals from inter-continental field data on river macroinvertebrates, Environ. Pollut., 166, 182, 2012.

4. GUSWA A.J., BRAUMAN K.A., BROWN C., HAMEL P., KEELER B.L., SAYRE S.S. Ecosystem services: Challenges and opportunities for hydrologic modeling to support decision making, Water Resour. Res., 50 (5), 4535, 2014.

5. HU S., NIU Z., CHEN Y., LI L., ZHANG H. Global wetlands: Potential distribution, wetland loss, and status, Sci. Total Environ., 586, 319, 2017.

6. DING J., Li H., CUO L., Yi C. Water quality variation characteristics in stormwater period and on Weihe river time scale, Polish J. Environ. Stud., 26 (6), 2495, 2017.

7. PRIGENT C., PAPA F., AIRES F., JIMENEZ C., ROSSOW W.B., MATTHEWS E. Changes in land surface water dynamics since the 1990s and relation to population pressure, Geophys. Res. Lett., 39 (8), 2012.

8. BENDOR T. A dynamic analysis of the wetland mitigation process and its effects on no net loss policy, Landsc. Urban Plan., 89, (1-2), 17, 2009.

9. GOLDBERG N., REISS K.C. Accounting for Wetland Loss: Wetland Mitigation Trends in Northeast Florida 2006-2013, Wetlands, 36 (2), 373, 2016.

10. SROCZYNSKA K., CLARO M., KRUK A., WOJTALFRANKIEWICZ A., RANGE P., CHICHARO L. Indicator macroinvertebrate species in a temporary Mediterranean river: Recognition of patterns in binary assemblage data with a Kohonen artificial neural network, Ecol. Indic., 73, $319,2017$.

11. AAZAMI J., ESMAILI SARI A., ABDOLI A., SOHRABI H., VAN DEN BRINK P.J. Assessment of Ecological Quality of the Tajan River in Iran Using a Multimetric Macroinvertebrate Index and Species Traits, Environ. Manage., 56 (1), 260, 2015.

12. REISS k.C., HERNANDEZ E., BROWN M.T. Application of the landscape development intensity (LDI) index in wetland mitigation banking, Ecol. Modell., 271, 83, 2014.

13. CLARE S., CREED I.F. Tracking wetland loss to improve evidence-based wetland policy learning and decision making, Wetl. Ecol. Manag., 22 (3), 235, 2014.

14. SARTORI L., CANOBBIO S., CABRINI R., FORNAROLI R., MEZZANOTTE V. Macroinvertebrate assemblages and biodiversity levels: Ecological role of constructed wetlands and artificial ponds in a natural park, J. Limnol., 74 (2), 335, 2015.

15. MEDRANO V., CHAMORRO A. Management plan for the conservation of endangered bird species in Lake Chinchaycocha, Asoc. Ecosistemas Andin., 85, 2010.

16. NATIONAL WATER AUTHORITY. Monitoreo participativo de la calidad del agua del lago Chinchaycocha (época de avenida) Junín-Pasco. 78, 2014.

17. SERNANP. Wetlands in protected natural areas, sources of life and development, Minist. Environment., 73, 2017.

18. APHA/AWWA/WEF. Standard Methods for the Examination of Water and Wastewater, Stand. Methods, 541, 2012.

19. DE ROSEMOND S., DURO D.C., DUBÉ M., Comparative analysis of regional water quality in Canada using the Water Quality Index, Environ. Monit. Assess., 156 (1-4), 223, 2009.

20. TERRADO M., BARCELÓ D., TAULER R., BORRELL E., DE CAMPOS S., BARCELÓ D. Surface-water-quality indices for the analysis of data generated by automated sampling networks, TrAC - Trends in Analytical Chemistry, 29 (1), 40, 2010.

21. MORENO C.E., Methods to measure biodiversity. ORCYT UNESCO, 2001.

22. BEZDEK J.C., PAL N.R. Some new indexes of cluster validity, IEEE Trans. Syst. Man, Cybern. Part B Cybern. 28 (3), 301, 1998.

23. MINEN. Approve Environmental Quality Standards (ECA) for Air and establish complementary provisions, El Peru. Off. Newsp., 6-9, 2017.

24. CCME. Canadian water quality guidelines for the protection of aquatic life, CCME water quality index: technical report, 2007.

25. WHO. WHO | Guidelines for drinking-water quality, fourth edition, WHO, 2011. .

26. KARA G.T., KARA M., BAYRAM A., GÜNDÜZ O. Assessment of seasonal and spatial variations of physicochemical parameters and trace elements along a heavily polluted effluent-dominated stream, 189 (11), 1, 2017.

27. CRAFT C., VYMAZAL J., KRÖPFELOVÁ L. Carbon sequestration and nutrient accumulation in floodplain and depressional wetlands, Ecol. Eng., 114 (2017), 137, 2017.

28. EFFENDI H. River Water Quality Preliminary Rapid Assessment Using Pollution Index, Procedia Environ. Sci. 33 (2016), 562, 2016.

29. . LI B., LI X., BOUMA T.J., SOISSONS L.M., COZZOLI F., QUANCHAO W., ZHOU Z., CHEN L. Analysis of macrobenthic assemblages and ecological health of Yellow River Delta, China, using AMBI \& M-AMBI assessment method, Mar. Pollut. Bull., 119 (2), 23, 2017.

30. KUZMANOVIC M., DOLÉDEC S., DE CASTRO. CATALA N., GINEBREDA A., SABATER S., MUÑOZ I., BARCELÓ D. Environmental stressors as a driver of the trait composition of benthic macroinvertebrate assemblages in polluted Iberian rivers, Environ. Res., 156 (March), 485, 2017. 
31. AYANDIRAN T.A., FAWOLE O.O., DAHUNSI S.O. Water quality assessment of bitumen polluted Oluwa River, South- Western Nigeria, Water Resour. Ind., 19 (December 2017),13, 2018.

32. CONY N.L., FERRER N.C., CÁCERES E.J. Evolution of the trophic state and phytoplankton structure of a Somero lake in the Pampean region: Laguna Sauce Grande (Province of Buenos Aires, Argentina)., Biol. Acuática, 30, 79, 2016.

33. KILUNGA P.I., SIVALINGAM P., LAFFITE A., GRANDJEAN D., MULAJI C.K., DE ALENCASTRO L.F., MPIANA P.T., POTÉ J. Accumulation of toxic metals and organic micro-pollutants in sediments from tropical urban rivers, Kinshasa, Democratic Republic of the Congo, Chemosphere, 179, 37, 2017.

34. BHUYAN M.S., BAKAR M.A., AKHTAR A., HOSSAIN M.B., ALI M.M., ISLAM. Heavy metal contamination in surface water and sediment of the Meghna River, Bangladesh, Environ. Nanotechnology, Monit. Manag., 8 (August 2016), 273, 2017.

35. CAPOLUPO M., FRANZELLITTI S., KIWUAN A., VALBONESI P., DINELli E., PIGNOTTI E., BIRKE M., FABBRI E. A comprehensive evaluation of the environmental quality of a coastal lagoon (Ravenna, Italy): Integrating chemical and physiological analyses in mussels as a biomonitoring strategy, Sci. Total Environ., 598, 146, 2017.

36. SCHINTU M., MARRUCCI A., MARRAS B., GALGANI F., BUOSI C., IBBA A., CHERCHIA. Heavy metal accumulation in surface sediments at the port of Cagliari (Sardinia, western Mediterranean): Environmental assessment using sequential extractions and benthic foraminifera, Mar. Pollut. Bull., 111 (1-2), 45, 2016.

37. HU Y., DONG, G. LI U. Distribution and potential ecological risk of heavy metals accumulated in subsidence lakes formed in the Huainan Coalfield, China, Environ. Forensics, 18 (4), 251, 2017.

38. JIA Y., WANG L., OU Z., YANG Z. Distribution, contamination and accumulation of heavy metals in water, sediments, and freshwater shellfish from Liuyang River, Southern China, Sci. Environ. Pollut. Res., 40 (3), 90, 2017.

39. MONROY M., MACEDA-VEIGA A., DE SOSTOA A. Metal concentration in water, sediment and four fish species from Lake Titicaca reveals a large-scale environmental concern, Sci. Total Environ., 487 (1), 233, 2014.

40. HAJI GHOLIZADEH M., MELESSE A.M., REDDI L. Water quality assessment and apportionment of pollution sources using APCS-MLR and PMF receptor modeling techniques in three major rivers of South Florida, Sci. Total Environ., 566-567 (2016), 1552, 2016.

41. HAO R.X., LI S.M., LI J.B., ZHANG Q.K., LIU F. Water quality assessment for wastewater reclamation using principal component analysis, J. Environ. Informatics, 21 (1), 44, 2013.

\section{Supplementary Material}
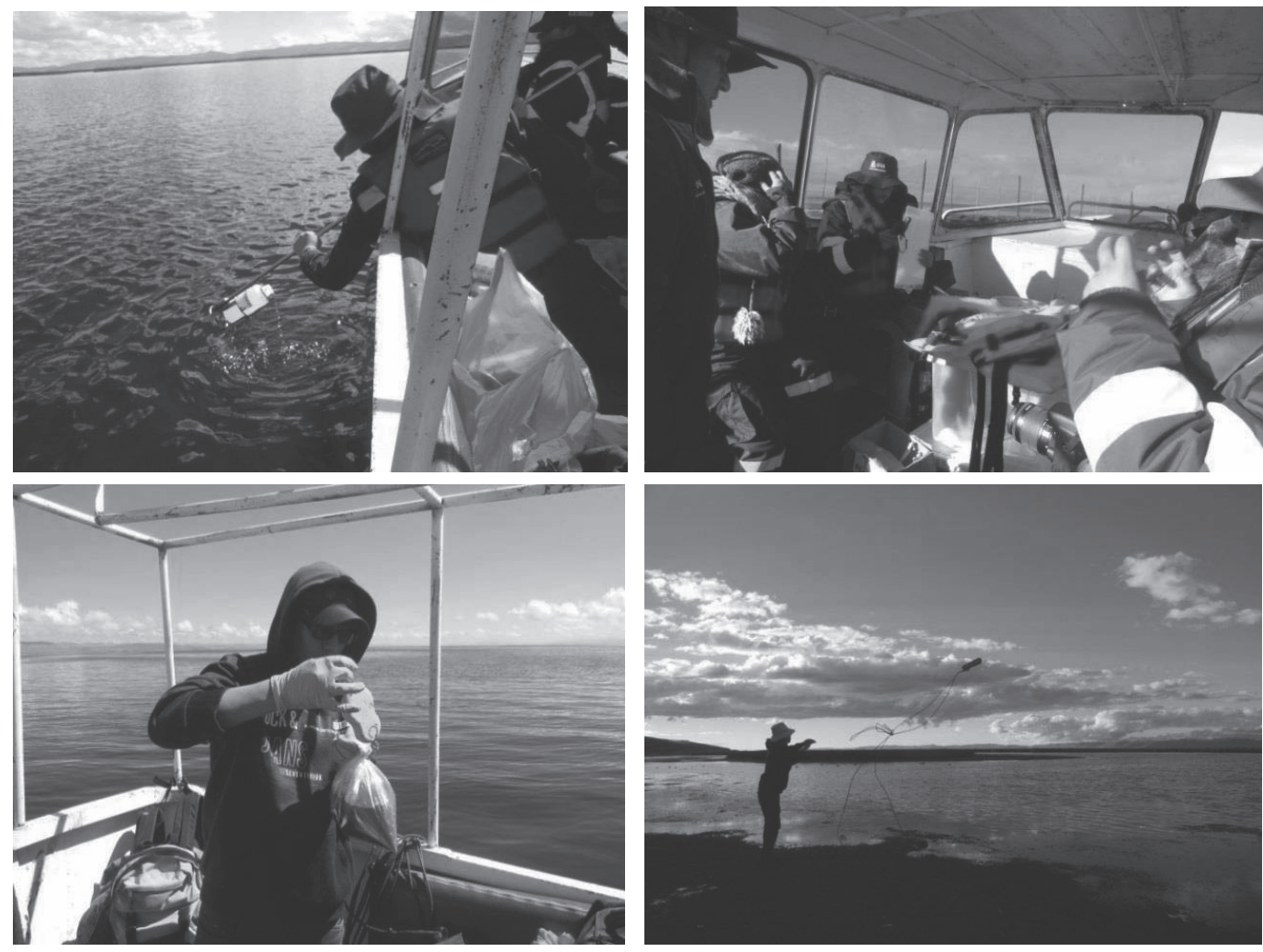

Fig. 1S. Water and sediment sampling in Lake Chinchaycocha. 
